\title{
上颛骨切除後の欠掑部即時再集術について
}

\author{
高橋庄二郎・城口精一・黄国 和
}

杉绮正志・内山健志・中村堅一

\section{Primary reconstruction of the defects after maxillary resection}

\author{
Shojiro Takahashi - Seiichi HoriguchI - Kunikazu Kõ \\ Masashi Sugrsaki - Takeshi UchiYama - Kenichi NaKamura
}

I. 粕

\section{曹}

最近, 上顥骨切除後に生じる欠損部の閉鎖，安定性の 高い義歯調製ならびに外钼の改善などを目的とした上類 骨再建術が部の人々によって行われている1 し，このような再建術は悪性腫汪手術後の症例に実施さ れるため，ほとんど 2 次的再建術である。著者らは上顎 骨に発生した悪性腫瘍以外の病变 4 例に対して, 口内法 または顔面皮切のるとで，片側上顥骨部分切除術を行い， さらに新鮮自家腸骨移植による欠損部の即時再建術を施

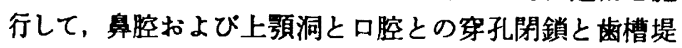
の形成に成功したので，本手術法の概要について報告す る.

\section{II. 手 術 法}

手術に先立って上䫑の石高模型を調整し，粘膜切開線 の位置や骨切除部の範囲を十分に検討しておく. 手術は 煡側経奥插管，あるいは経口插管による気管内麻酔下 K，顔面皮切のもとで，あるいは口内法で行5。顔面皮 切はできる限り小範囲にとどめるよ5に努める。すなか ち顔面皮切は Weber 切開を避け，上唇正中分割，患側 外番孔底部および毫翼周辺部に施す（写真 1-c)，粘膜 切開は移植骨片を軟組織で完全に被覆できるように歯頸 部付近に行う。次いで，上䫑骨前面および側面を広く開 故する，口蓋側では患側または健側を含めた口蓋粘膜骨 膜弁を形成する。 この際，健側を含めるかどらかは口蓋 睢に怙ける骨切り部の位置によって決定する，大口蓋神

東京科大学口腔外科学教室第 2 講座（主任：高 橋庄二郎)

The Second Department of Oral Surgery, Tokyo Dental College (Chief: Prof. Shojiro Takahashi)

受付日：昭和53年 6 月 7 日
経血管束は口蓋弁に含めるか，弁の側方移動を容易にす るため, 神経血管束を大口蓋孔から引き出すとともに， 口蓋弁を反転して神経血管束の両側骨膜を切離し，口蓋 升から神経血管束を一部分離させる。

骨切りは注水下に fissure bur 拉よび Lindemann bur を用いて行ら、すなわち，まず前方骨切り部の雪牙を抜去 したのち, 歯棌突起の頓舌的完全骨切りを行5.上頻外側 の骨切り部は症例によって巽なり，梨状口側緣や鼻腔側 壁または頓骨などを含める場合と，そらでない場合とが ある， 口蓋側では大口蓋神経血管束や粘膜を損稘しな いよ5に骨切りを進める，後方に打いて上䫑結節部を含 めて切除する場合には，Obwegeser の開発した pterygomaxillary osteotome を用いて翼状上䝷結合部の分離を 図る，最後に，骨ノミを用いて完全骨切りを行い，算粘 膜をできる限り損賃しないよらに注意しながら類骨を切 除する。

その後，適当量の自家腸骨片を採取し，犬歯部に相当 する部位で正常歯槽堤に近い篹曲をつくり（写直 2-E), 前方で紫槽突起骨切り面, 後方で頓骨骨切り面または翼 状突起ないし歯槽突起骨切り面に接するごとく，腸骨片 を金属線による骨継合によって固定する，上顎洞粘膜は 一部損賃されるが，強い感染をきたしていない限りその ままとする。しかし鼻粘膜の断裂した場合には，これを 䋖合閉鎖するように努める，次いで，軟組織による移植 骨片の完全被覆を図るため， 口蓋弁中央部から移植骨片
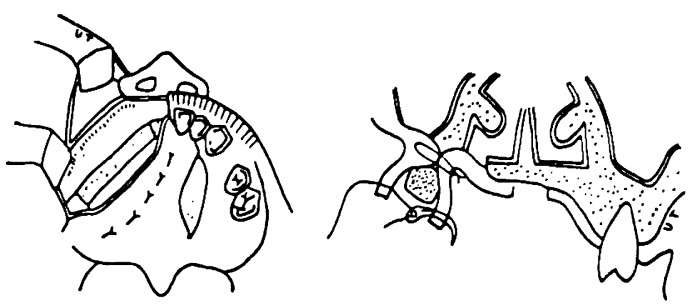

図 1 上䫑骨切除後の欠損部即時再建法 

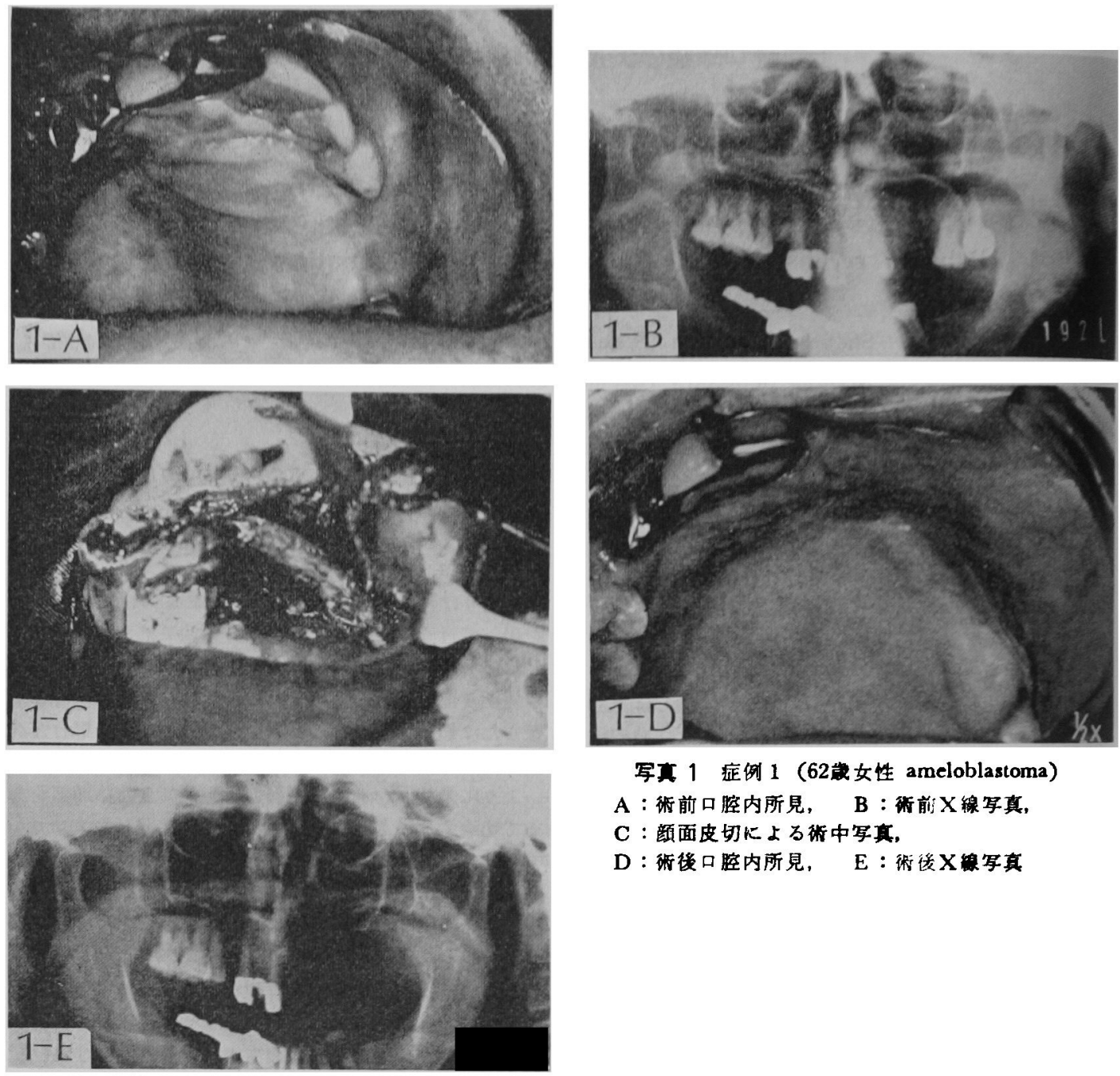

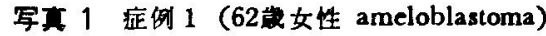
A : 得前口璌内所見,
B : 郝前 X楾写真,
C：颜面皮切に上る術中写真,

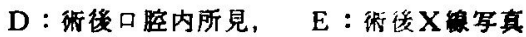

の上を通り，頓部筋層に至る多数の mattress suture を

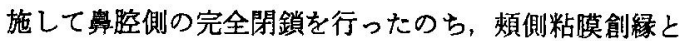
口蓋弁側縁を繸合して口腔側を閉鎖する（図１）.最後に， 口蓋升移動によって生した骨露出面に抗生物質軟弯を祭 布したガーゼを挿入し，創面の保護と移植骨の固定性を 高めるため，あらかじめ作製しておいたレジン床に軟化 したモデリングをるって印象採得し，これを健側崡牙人 の結紮和よび患側頓骨弓を通る suspension wiringによ って固定する。なお，この保護床は術後 7 ～10日で除去 する，口蓋升中央部で結禁された mattress suture はで きる限り長期間残して括く。

\section{III. 症例}

症例 1 (写真 1)，62 歳女子の 左側上䪽部に発生した ameloblastoma である. 左側鮢翼基部より上煩部にわた って無痛性腫脹が存在し，口腔内では|上より|7に至る 潾槽部が煩舌㑡ともに著明の膨隆を示し，口蓋側では一

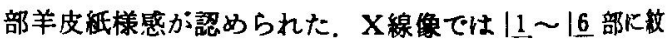
理様の骨吸収像があり，また隀捣によって上額洞底や下 鼻道側壁が王迫されている像がみられた。

本例では上唇正中完全分割，左側外聴孔底部ならび 鼻翼周辺皮切，健側を含む大きな口蓋弁形成のもとに， |1から|7にわたる上顥骨を切除した，なお梨状口湖 绿，奥腔側壁，煩骨の一部は切除骨片内に含めたまた 口蓋側の骨切りは正中に近い部位でこれを行った，骨切 除時、上方に圧迫された上顎洞底の粘瞙が消失し，下鼻 道の一部に開放を生じた。腸骨片は前方歯槽突起骨切り 面および煩骨骨切り面に固定した。

後術 2 週目に移植骨片の前方部が一部露出したのて， 

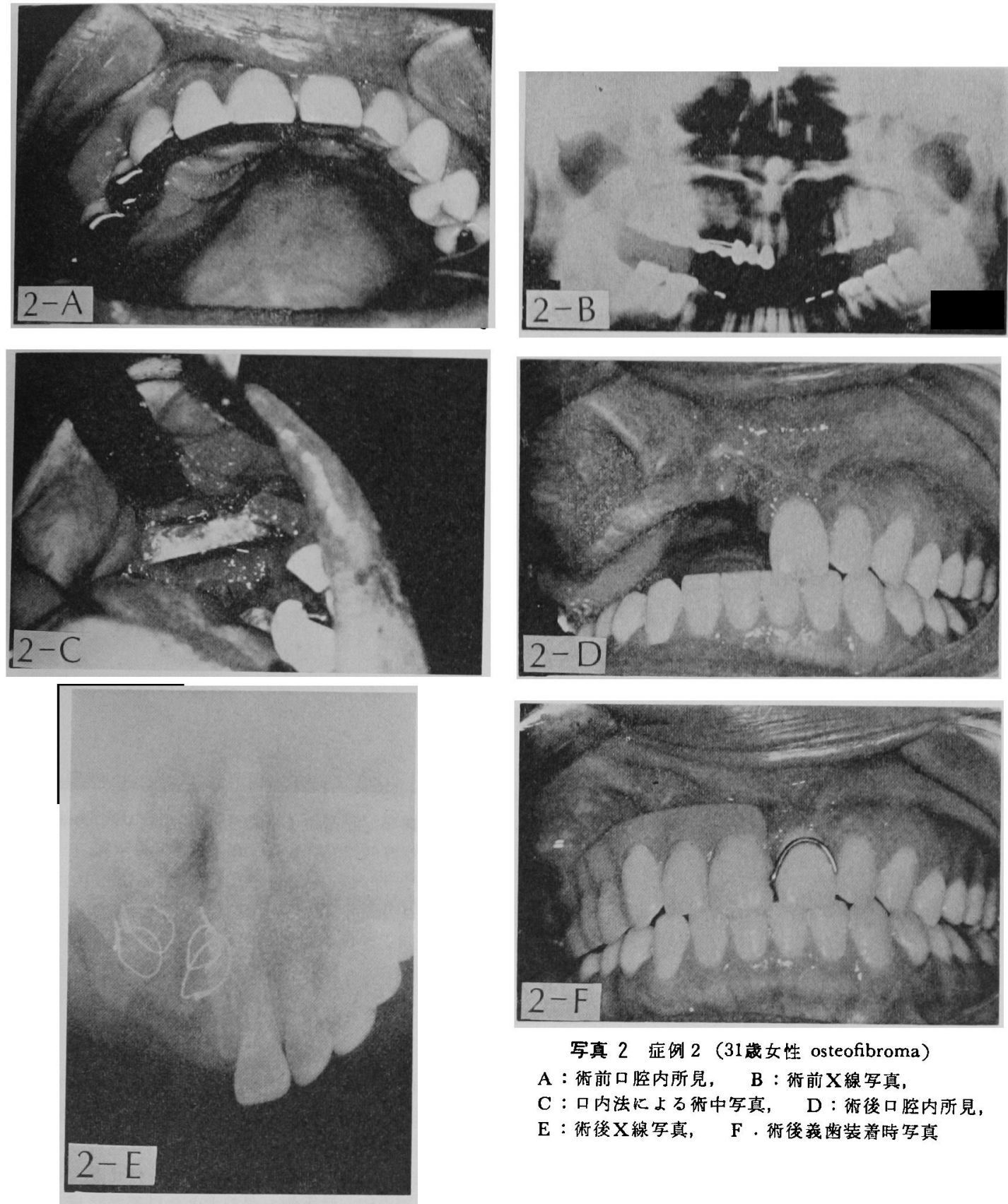

写真 2 症例 2 (31恳女性 osteofibroma)
A：術前口腔内所見， $B$ ：㭪前 $X$ 線写真，
C：口内法に上る要中写真， D : 犹後口腔内所見，

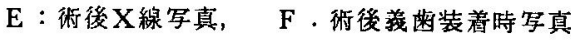

口唇粘膜弁を形成して骨面の被覆を図った，本例では犬 歯部の彎曲をつくらなかったため，形成された歯槽堤が やや直線状を呈し，しかる口腔前庭が浅かったので，術 後 1 年 2 か月目に分層植皮を用いる口腔前庭形成術を行 った.

症例 2 (写真 2)，31歳女子の右側上顎部に 発生した osteofibroma である，本例は 8 年前と 5 年前に当科に括

いて osteofibroma の診断のもとに骨膨隆部を削去する 保存的手術が行われたが，再発をきたしたものである。 当部付近から大日歯部にわたって䫅舌側歯槽部に骨様 膨隆が認められたが，残存齿の骨植は良好であった。 $\mathrm{X}$ 線像では $2 \mid$ から 6 |にわたる歯槽部にスリガラス状の陰 影が認められ，断層前額断X線写真に打いて上䫚洞底が 健側に比へてかなり上方に挙上されていた。 

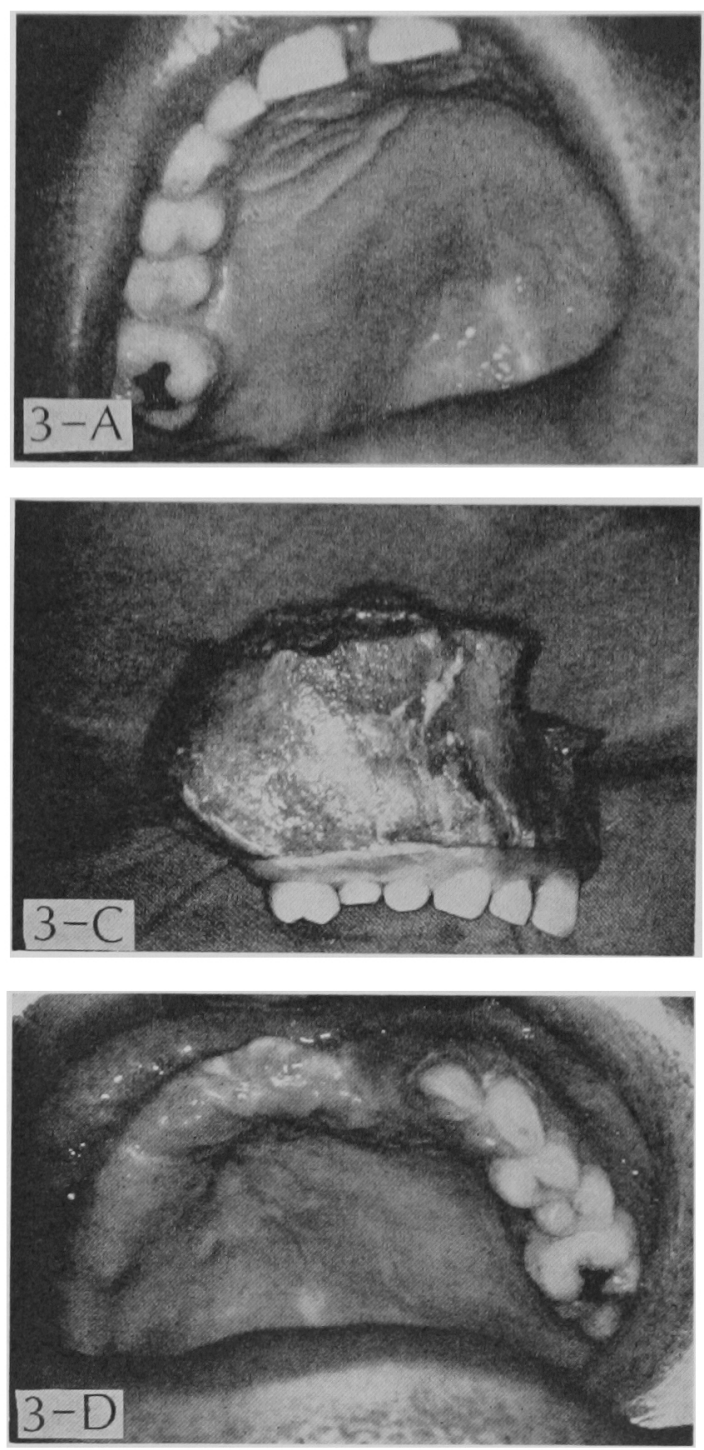

この症例に対しては口内法による手術を行った，骨切 除は正より 6 |にわたる部位に行ったが，梨状口側縁や 腔側壁はこれらを残存させた。な扣蓋升は患側のみ で形成した，移植骨片は犬歯部に相当する部位で切断

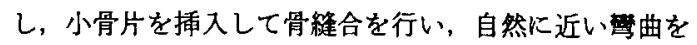
得るように图り，前方执よび後方歯槽突起骨切り面に骨 释合によって固定した，本例でも上䫇洞粘膜の一部が消 失したが，移植骨片は完全に生着し，かなり高い歯槽堤 が形成されたので，口腔前庭形成術を施行する必要はな かった.

症例 3 (写真 3)，28 歳男子の 右側上䫑部に発生した fibrous dysplasia である. 11より右側上靧結節部に至
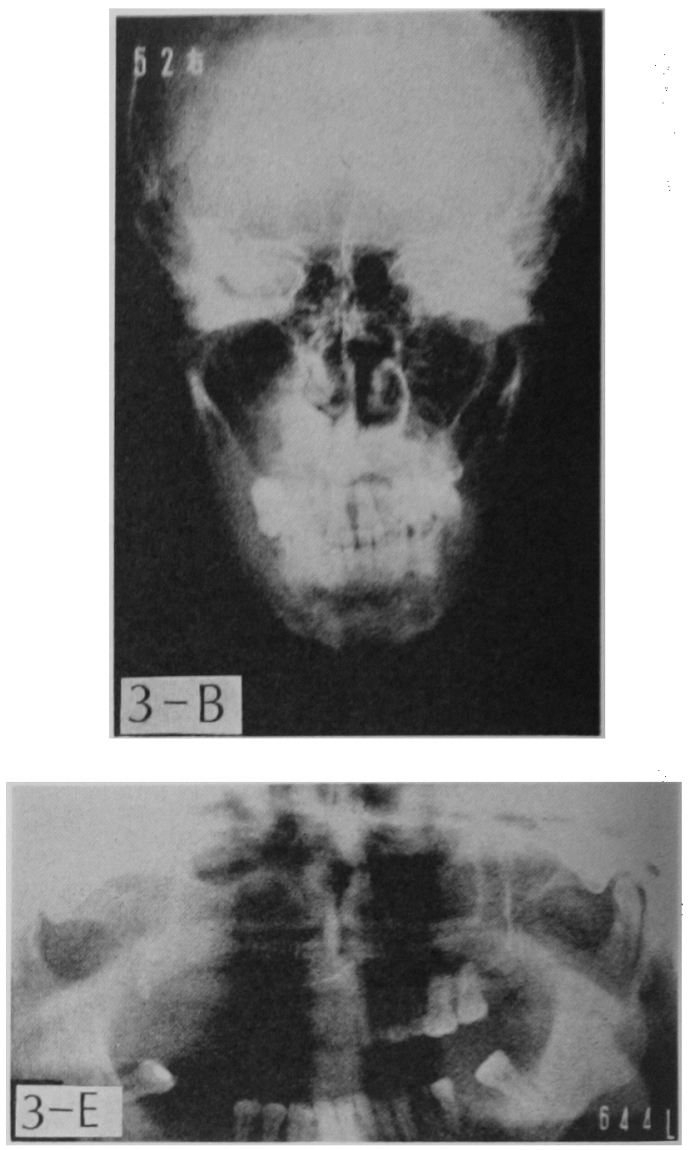

写真 3 症倒 3 (28瓷男性 fibrous dysplasia)
$A ：$ 行前口腔内所見, B : 街前X線写真,
$\mathrm{C}:$ 摘出物， D：㧓啳口圈内所見，
$\mathrm{E} ：$ 得後X線写真

る煩舌側の無痛性骨膨隆が諗められた。 X楾像では红 から 8 | 部に骨棱の消失した斑点状不透過像があり，こ れにより上額洞底や下鼻道側壁が压迫されていた。

本例では上髣正中完全分割，右㑡外鼻孔底部ならびに 累翼周辺皮切，健康側を含む大きな口蓋弁形成のむと に，1上から右側上䫑結節部に 至る上額骨を切除した。 なお梨状口側縁, 奥腔側壁, 禎骨の一部は切除骨片内に 含めた。後方部は糸状上影結合部で切離した．また洞秥 膜の肥厚および一部感染がみられたため，これを娳離摘 出した，腸骨片は犬歯部に相当する部位で切断し，槽 堤に近い朁曲を形成したのち，前方雪槽突起骨切り面お よび翼状突起切離面に骨释合によって固定した。 

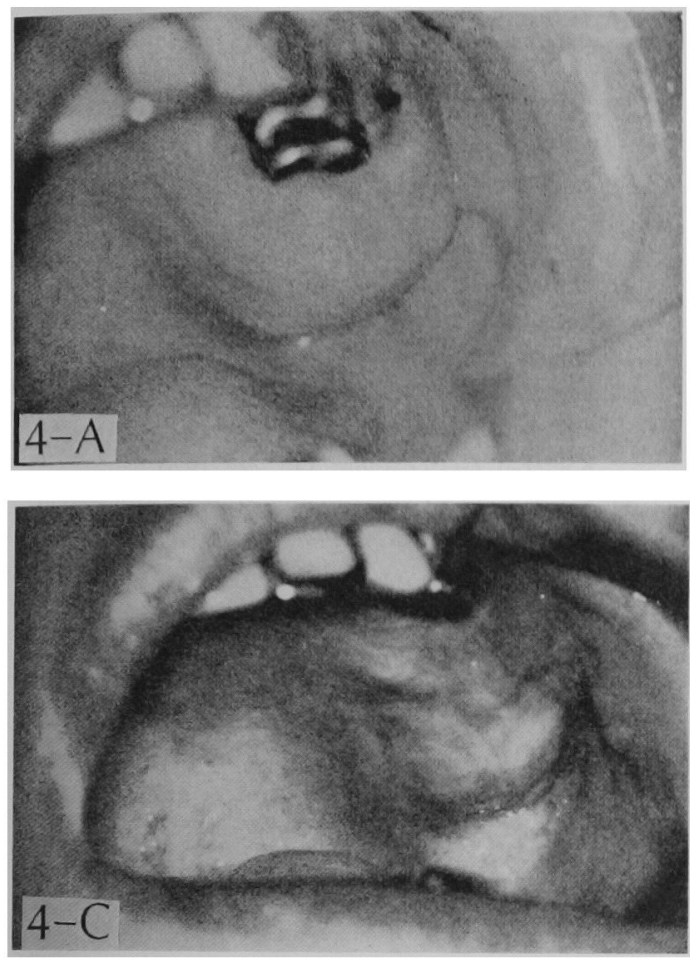

症例 4 (写真 4)，38 歳女子の左側上頻部に発生した fibrous dysplasia である。14より左側上類結節部に至 る煩舌側の無痛性骨膨隆が認められた．X線像では」出 から左㑡上靧結節部に骨稜の消失した斑点状不透過像が みられた。

本例に対しては口内法による手術を行った，骨切除は 出より上顎結節を含んで行ったが，上買洞底は一部を除 いて残存させた，口蓋弁は健側を含んで形成した。移植 骨片は前方幽槽突起骨切り面と煩骨骨切り面に金属線に よる骨程合を行って固定した。

\section{IV. 考察}

上頻骨切除患者に対しては，欠損部の閉鎖，言語障 害, 瞼下障害, 咀獣障害など各種口腔機能障害の排除, 外観の改善などを目的として古くから顠補㥪が行われて

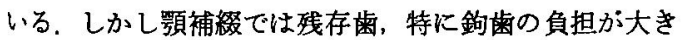
いため，残存崡の早期破壊をきたし，保持力および維持 力の極度に悪い補綴物となり易い，また銁霜消失のない るのでも，十分な機能圧を負担しらる骨組織が存在しな いため, 顎補経による咀嚼能力回復は通常の義茵に比べ て著しく劣ることは当然である。

近年, 多くの人々によって上顎骨切除後の欠損に対す る再建術が行われるようになった。 この再建術はは軟組
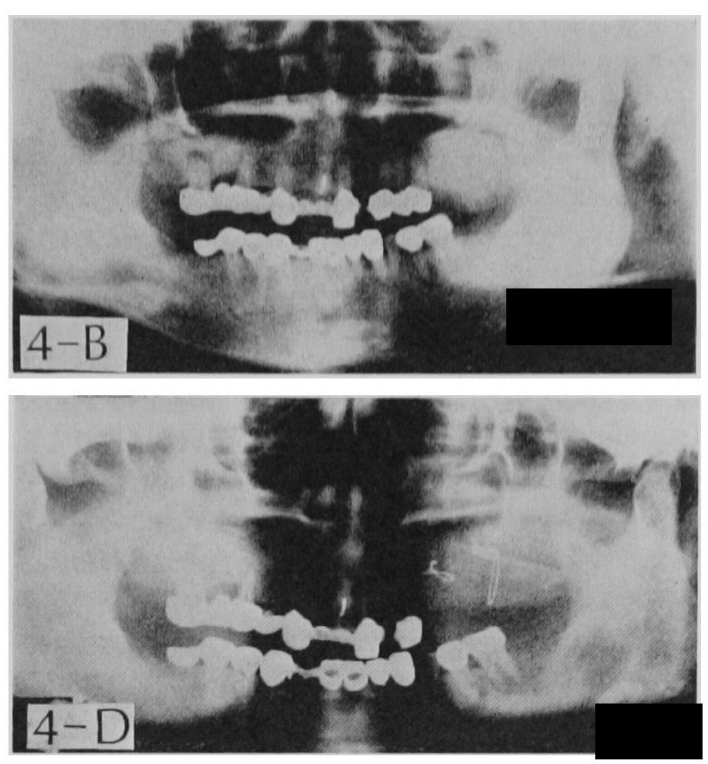

写重 4 症例 4 (38踥女性 fibrous dysplasia)
A：帏前口羫内所見，
$\mathrm{B}$ : 行前 X線写真,
C：得後口控内所見，
$\mathrm{D}$ : 得後X線写真

織のみで久損閉鎖を四る方法と，さらに骨移植によって 畨槽堤むで形成する方法とがある．上額の欠損が比較的 小さい場合には局所組織のみで閉鎖を図ることができる が，これが著しく大きな場合には遠隔弁を用いざるを得 ない2 2 .

最近, Obwegeser ${ }^{1,2)}(1967,1973), \operatorname{Schmid}^{3)}$ (1970) らは骨移植によって歯槽堤を形成するとともに外観の改 善を図る上頡骨再建術を発表している，しかし彼らの症 例はいずれる悪性腫湶による上颗骨切除患者であるた め，晚期再建術を行ったものである. Obwegeser ${ }^{2}$ (1973) は上買骨切除後の即時再建術は患者にとってもきわめて 有利であるが，悪性腫場患者では再発の危險性が高いた め，最初は影補綴を利用させ，再発の可能性がないと判 断されたのちに上顎再建術を施行すべきであると述べて いる。

悪性腫瘍以外の病変による下罰骨切除患者に対して は，骨移植による即時再建術が行われ，これが形態的に む機能的にるきわめて良好な結果の得られることが広く 認められている8) そこで著者らは，上顎骨に発生した 良性ないし中間型腫場抽よび病変 4 例に対して，片側上 額骨部分切除後腸骨移植に上る即時再建衍を施行し，き わめて良好な結果を得た。 また最近，口内法による下顎 骨切除と即時再建術が一部の人々によって行われてい $3^{8 \sim 17)}$. 
著者らもこのよらな手術を多数例に知施しているが， 今回郝告した上頻情再趣例 4 例のろち 2 例は口内法に上 るものである.

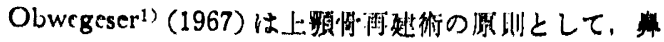

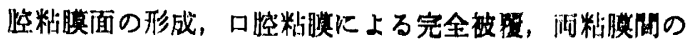

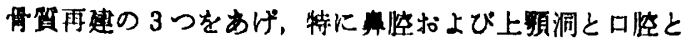

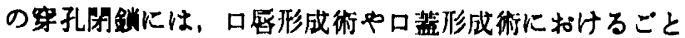

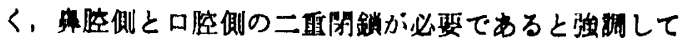

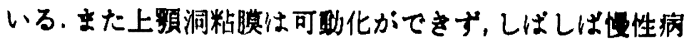

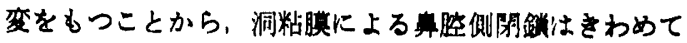
不满足であると述へてている。著省らの症例はいずれる影

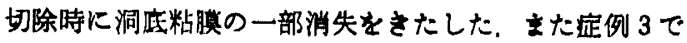
は洞粘膜の肥质および一部感染が思められたことから，

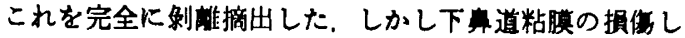

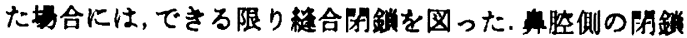
には著者らは十分に可動化した口蓋茾のほぼ中央部から 煩部筇周に至る多数の mattress suture を行い，それら の抜釆をできる限り延期した。 またここの操作によって， かなり深い口腔前庭を形成することができた，口腔前庭 形成術を必要としたものは症例1のみであった，Obwegeser $^{1,2)}(1967 ， 1973)$ は移植骨に胁骨と腸骨とを用いて いるが，著者らの症例はいずれむ成人であったことか ら、すへてて腸骨を用いた。移植骨片は前方では歯槽突起 骨切り面に骨䉽合を行って固定したか，後方では煩骨骨 切り面, 畨突起骨切り面, 翼状突起など症例によって 異なった部位に固定した。 また骨片固定をさらに強固に するため，口蓋保護床を用いた。 なお解剖的な粘槽堤を 形成するためには，犬觜に相当する部位で移植骨片を學 曲させることが必要であると思われた。

以上のごとき上額骨切除後の欠損部即時再建術は，顔 面変形を著しく予防できるばかりでなく，腔および上 頻洞と口腔との穿孔閉鎖が得られるので，言語障害や哭 下障害をきたすことがなく，しかる義齔の機能圧を負担 しらる歯槽堤を形成することができる。したがって，頻 切除による患者の心理的影警はきわめて小さく，患者の 早期社会復帰が得られるすのと考えられる.

\section{V. 結論}

上顥骨に発生した悪性腫瘍以外の腫掦ないし病変 4 例 に対して, 片側上額骨部分切除後, 腸骨移植による即時 再建術を行い，良好な結果を得た。本手術によって欠損 部閉鎖とともに，安定性の高い義雪を調整しらる齿槽堤 を形成することができた。このような手術法を適応すべ き症例は口腔外科の領域ではかなり多いものと考学られ る.

本論交の要旨は第31回日本口腔科学会総会（昭和52年 5 月14日), 第21回日本形成外科学会総会 (昭和53年 3 月
17日）に颃いて辄结した。

\section{引用文 䤊}

1) Obwegeser, H.L.: Die Rekonstruktion von Defekten nach Oberkieferresektion. Disch zähnärztl z 22: 15081967.

2) Obwegeser, H.L.: Late reconstruction of large maxillary defects after tumor-resection. J max-fac Surg 1: 191973.

3) Schmid, E.: Die Wiederherstellung des Oberkiefers nach Sarkomoperation. Fortschr Kiefer-u Gesichtschir 14: 2571970.

4) Kostrubala, J.G.: Repair of extensive palate defects with skin tubes. Plast Reconst Surg 5: 5121950.

5) Longacre, J.J., Gilby, R.F.: Reconstruction of scarred palatal defects. Plast Reconst Surg 14: 3571954.

6) Edgerton, M.T., et al.: Reconstruction of palatal defects resulting from treatment of carcinoma of palate, antrum or ginigva. Plast Reconst Surg 28: 3061961.

7) Elliott, R.A. Jr.: Use of nasolabial skin flap to cover intraoral defects. Plast Reconst Surg 58: 2011976.

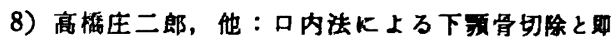
時再建㭪について。 日外誌 22：478 1976.

9) Nasteff, D.: Intraorale Kieferresektion. Praxis 9: 181958.

10) Nasteff, D.: Frühzeitige Wiederherstellung des Unterkiefers nach Resektion oder Exartikulation. B Zahnh 26: 471965.

11) Heidsieck, C.: Entfernung gutartiger Kiefertumoren und osteoplastische Defektdeckung bei enoralem Vorgehen. Fortschr Kiefer-u Gesichtschir 7: 1981961.

12) Obwegeser, H.L.: Probleme und Möglichkeiten der Unterkieferresektion und gleichzeitigen Rekonstruktion auf dem oralen Operationsweg. Schweiz Monatschr Zahnh 73: 8301963.

13) Obwegeser, H.L.: Erfahrungen mit der einzeitigen Unterkieferresektion und Rekonstruktion auf dem oralen Operationsweg. Oesterr Ztschr Stomatol 62: 2611965.

14) Obwegeser, H.L.: Simultaneous resection and reconstruction of parts of the mandible via the intraoral route in patients with and without gross infections. OS OM OP 21:693 1966.

15) Obwegeser, H.L.: Primary repair of the mandible by the intraoral route after partial resection in case with and without preoperative infection. Brit J Plast Surg 21: 382 
1968.

16) Celešnik, F.: Intra-oral osteoplastic operations. Acta chir plast 5: 2661963.

17) Sailer, H.F.: Experiences with intra-oral partial resection and simultaneous reconstruction of the mandible in preoperatively noninfected cases. J max-fac Surg 2: 1731974. 